\title{
Review of Soybean Resistance to Pathogens
}

\author{
Miloš Vidić • Vuk Đorđević • Kristina Petrović • Jegor Miladinović
}

\author{
received: 20 June 2013, accepted: 9 October 2013 \\ published online: 15 November 2013 \\ (C) 2013 IFVC \\ doi: $10.5937 /$ ratpov $50-4038$
}

\begin{abstract}
Summary: This paper presents an overview of the research on soybean resistance to pathogens. The review included most harmful agents of soybean diseases in Serbia, as well as those that are potentially harmful. Development and cultivation of resistant cultivars is the most efficient, economical and environmentally acceptable control measure for plant disease. It points to the variability in pathogenicity (physiological races) of parasites, especially expressed in Phytophthora sojae, Peronospora manshurica and Pseudomonas syringae pv. glycinea, which requires continuous breeding for resistance. Resistant, partially resistant and moderately susceptible genotypes, which are used as donors of resistance genes to different pathogens, are listed in this paper. Also, avirulent genes in the parasite and resistance genes in soybean are indicated. Gene mapping significantly contributes to better understanding of the mode of inheritance and consequently, more efficient breeding for disease resistance. Significant improvement is expected by using molecular techniques, especially in dealing with Sclerotinia sclerotiorum, Pseudomonas syringae pv. glycinea and Phomopsis longicolla. For these parasites only partial resistance has been reported but not complete resistance.
\end{abstract}

Key words: pathogens, resistance, soybean

\section{Introduction}

A large number of phytopathogenic microorganisms are parasites on soybean (Glycine $\max (\mathrm{L}$.) Merr.), and they cause various pathological changes in plants. More than 135 pathogens of this crop were described, and it is considered that about 30 species can cause significant economic damage (Roy et al. 2000). The most harmful are fungi, then bacteria, viruses and phytoplasmas. In an agro-ecological region, several pathogens usually occur with high intensities, while others are either not present, or occur sporadically. In the last thirty years, many parasites causing diseases on soybean in Serbia were described (Vidić \& Jasnić 2008). The problem of diseases becomes more emphasized because the areas under this crop are increasing. Based on many years of evaluating the disease intensity, it was found that the most frequent soybean parasites are Peronospora

\footnotetext{
M. Vidić • V. Đorđević* • K. Petrović • J. Miladinović

Institute of Field and Vegetable Crops, 30 Maksima Gorkog, 21000

Novi Sad, Serbia

e-mail: vuk.djordjevic@nsseme.com
}

manshurica (downy mildew) and Pseudomonas syringae pv. glycinea (bacterial blight) on leaves, then Diaporthe phaseolorum var. caulivora (stem canker) and Sclerotinia sclerotiorum (white mould) on stems, Macrophomina phaseolina (charcoal rot) on root, and Phomopsis longicolla which are the main causes of seed decay (Vidić \& Jasnić 2008). In addition, there are other soybean pathogens which occur sporadically, although epiphytotic attacks have been reported in some years.

The aforementioned soybean pathogens can cause significant damage and sometimes even question the profitability of soybean growing. Consequently, in suppression of soybean diseases it is necessary to apply all control measures recommended within integrated disease management. Since chemical measures are rarely applied, attention should be placed on the crop management practice and, cultivating resistant or less susceptible genotypes wherever possible.
Acknowledgements:

The authors would like to express their gratitude to the Serbian Ministry of Science and Education for financial support awarded to the scientific project TR31022. 
It is known that the development and spread of resistant or less susceptible genotypes of cultivated plants is the cheapest, most efficient and environmentally most acceptable disease control. Therefore, considerable attention is given to the introduction of the highest possible levels of resistance to parasites in most breeding programs.

Breeding for resistant cultivars is complex and consists of several phases. First of all, appropriate resistance sources (donors of resistance genes) are identified based on reactions of soybean genotypes to field infection or when tested under controlled conditions. Preferably artificial infection (inoculation) methods should be as similar to natural pathogenesis as possible. Breeding involves the use of resistant genotypes as one of the parents. Experimental lines are tested for disease resistance, in the same or similar manner as in initial screening for sources of resistance. Only the resistant or partially resistant lines continue to be tested for other important agronomic traits.

Considerable difficulties in soybean breeding for resistance to parasites result from the lack of adequate sources of resistance. The most obvious examples are $S$. slerotiorum (white rot) and $D$. phaseolorum var. caulivora (stem canker). Also, the variability in pathogenicity of parasites within the population (physiological races) often results in partial or complete loss of resistance. This phenomenon is characteristic of the vertical (race specific) resistance, which is complete but not permanent, because it is conditioned by the action of one or several genes with strong effect (major genes). For downy mildew (P. manshurica), Phytophthora root and stem rot (Phytophthora sojae) and bacterial blight (P. syringae pv. glycinea), numerous physiological races, changes in prevalent races and appearance of new one, breeding for resistance must be continuous.

This review summarizes the findings of previous studies on soybean resistance to pathogens. It presents the most important causal agents of soybean diseases in Serbia, as well as the potential ones. Also, the paper indicates soybean resistant genotypes to certain pathogens and types of resistance, and lists resistance genes and the modes of inheritance. Special attention is given to pathogen variability.

\section{Peronospora manshurica}

P. manshurica causes downy mildew in soybean and is a widespread disease in all soybean growing regions of the world (Sinclair \& Shurtleff 1975, Aćimović 1988). This pathogen usually parasitizes on leaves and causes premature defoliation. Yield losses of about $8 \%$ have been reported (Athow 1973), however in highly susceptible cultivars grown in favourable conditions for disease development, yield reduction can reach 25\% (Dunleavy 1987).

Successful breeding for resistance to $P$. manshurica in soybeans is possible because of the existence of good resistance sources. However, due to a number of physiological races and constant appearances of the new ones, soybean breeding requires continuous effort. The first three races of $P$. manshurica were identified by Geesman (1950a) in the United States, then Lehman (1953), Grabe \& Dunleavy (1959) and finally Dunleavy $(1971,1977)$ identified another 29 races, based on reactions in 14 differential genotypes. These races are marked with sequential numbers, ending with the number 32. Cultivar Union was resistant to all previously known races. Later, Lim et al. (1984) determined the race number 33, to which the cultivar Union was susceptible. These authors found that cultivars Pridesoy, Palmetto, Cabot, Ogden and Acadian were resistant to race 33. Marcinkowska (1991) allocated 11 races on soybean in Poland, from which seven were described for the first time and named with numbers from 34 to 40 .

In the middle of the $20^{\text {th }}$ century, Geesman (1950b) found that one dominant gene controlled soybean resistance to $P$. manshurica. Cultivars Kanrich and Pine del Perfection were resistant to races from 1 to 32 , and gene responsible for resistance marked by Rpm (Bernard \& Cremeens 1971, Ersek et al. 1982). Using the cultivar Kanrich as donor of resistance, in several backcrosses, new resistant commercial cultivars were developed. However, with the appearance of race 33, the resistance of those cultivars was lost. $\operatorname{Lim}$ (1989) found that the gene Rpm2, responsible for resistance to new race and race 2 , differs from the previously identified gene Rpm. Using RAPD analysis, Chowdhury et al. (2002) identified two markers (OPH-02 and OPP-10) associated with Rpmx gene, which controls the resistance to two unidentified races of $P$. manshurica. There is a possibility that gene $R p m x$ is identical with one of two previously mentioned resistance genes $(R p m$ and $R p m 2$ ).

In Serbia, pathological variability of $P$. manshurica has not been studied and races of this pseudo-fungus were not identified. The presence of several races is evident, given the observed gradual loss of resistance in completely resistant soybean genotypes (Vidić, personal observations). The Institute of Field and Vegetable Crops in Novi Sad keeps a collection of resistant soybean genotypes, which are used as sources of resistance to downy 
mildew. The most frequently used source of resistance was cultivar Colfax, which is a common parent in a few commercial soybean cultivars.

\section{Pseudomonas syringae pv. glycinea}

P. syringae pv. glycinea causes bacterial blight, the most widespread and harmful bacterial disease in soybean. It appears every year in Serbia with varying intensity on soybean (Tošić et al. 1986, Balaž et al. 1990, Ignjatov 2007). This pathogen causes disease symptoms in all aboveground organs of plants, mostly on the leaves and seedlings. It has been observed that a more intensive attack can significantly reduce yield (Williams \& Nyvall 1980, Kennedy \& Alcorn 1980, Balaž \& Aćimović 2008).

Soybean genotypes express different degrees of susceptibility to certain isolates of $P$. syringae $\mathrm{pv}$. glycinea, which indicates the existence of several physiological races. This was first noticed by Cross et al. (1966), who identified seven races (1 to 7) based on the responses of seven differential genotypes, then Fett \& Sequera (1981) determined another two races (8 and 9), and Abo-Moch et al. (1995) determined the presence of a new race that was identified as number 10 while studying strains of P. syringae pv. glycinea originating from soybeans in Europe. The next two races (11 and 12) were found in China (GAO 1998). According to Cross et al. (1966), one genotype was usually colonized with one physiological race. Studying the race composition in the province of Vojvodina, Balaž et al. (1990) found that race 4 dominated this region and there were indications of the presence of another race, which exhibits most similarities with the race 5 . After almost 20 years, Ignjatov et al. (2007) confirmed that race 4 is still dominant on soybean in Vojvodina region. All these authors emphasized that this race was the most aggressive and most widespread of the disease on soybean in the world.

Inheritance of resistance to $P$. syringae pv. glycinea is the subject of numerous studies. It was found that different races have different avirulent (avr) genes capable of causing disease on host plant, only in the absence of specific plant resistance gene. First, Staskawics et al. (1984) found the avirulent gene avrA in race 6, which causes a hypersensitive (resistant) reaction on soybean genotypes with the resistance gene $R p g 2$. Later, avr $\mathrm{B}$ and $a v r \mathrm{C}$, were determined in races 0 and 1 , and the corresponding $R p g 1$ and $R p g 3$ genes (Staskawicz et al. 1987). The avr $\mathrm{D}$ gene was found in the related bacterium Pseudomonas syringae pv.tomato, the pathogen on tomato (Kobayashi et al. 1989; 1990). When this avirulent gene ( $a v r \mathrm{D})$ was incorporated into the race 4 of $P$. syringae pv. glycinea, it was found that soybean genotypes with $R p g 4$ gene exhibited hypersensitive response (Keen \& Bazzell 1991). Since the source of resistance to race 4 does not exist in soybean genotypes, it is supposed that avr $\mathrm{D}$ in $P$. syringae pv. glycinea mutated and avoided soybean immune response (Keith et al. 1997). Recent studies indicate the existence of other three avirulent genes, designated $a v r \mathrm{E}, a v r \mathrm{~F}$ and $\operatorname{avr} \mathrm{G}$ in races 2, 3 and 8 (Farhatullah et al. 2011). According to these authors, complementary resistance genes for these avr genes are Rpg5, Rpg6 and Rpg7, respectively.

The dominant nature of race 4 in the field makes the work on soybean breeding for resistance to $P$. syringae pv. glycinea difficult, because there is no source of resistance. Before the advent of more virulent races, literature referred to several resistant soybean genotypes. A detailed overview of resistant cultivars was given by Aćimović (1988). However, after the appearance of a number of physiological races, such data became very scarce. Research in Serbia has shown that domestic commercial cultivars are susceptible to $P$. syringae pv. glycinea, which is one of the main causes of frequent and strong epiphytotic attack of bacterial blight on soybean crops. Based on natural infection and inoculations studies significant differences were observed in the degree of susceptibility. It was concluded that the early-maturing genotypes are more susceptible than the late-maturing. Latematuring line P9241 expresses a satisfactory level of resistance to race 4 under field conditions, and a moderately susceptible reaction in artificial infection (Vidić \& Balaž, 1997). Also, the experimental line NS-L-220230 has a similar level of resistance to this bacterium (Ignjatov 2007). Both of these genotypes have been included in the soybean breeding programs at the Institute of Field and Vegetable Crops in Novi Sad. Several promising and moderately susceptible soybean lines were selected and are held in the collection at the Institute.

\section{Phytophthora sojae}

Phytophthora sojae is soil-borne oomycete that is host-specific to soybean, causing damping-off in seedlings, and root and stem rot in older plants. Commercially, it is one of the most important soybean pathogens, spread across all major soybean producing countries around the world (US, Argentina, Chile, France, Italy, Ukraine, Russia, Chine, Australia) (EPPO PQR). In Serbia, this pathogen has not yet been found. 
Resistance of soybean to $P$. sojae was usually explained in the framework of gene-for-gene model, which consist of the interaction between cultivar-specific resistance in a soybean plant and strain-specific virulence in a pathogen (Dong et al. 2011). The race specific interaction is determined by pathogen avirulence $(A v r)$, gene which encodes effectors that enable pathogen growth in soybean plant in the absence of appropriate host resistance $(R)$ gene. Host specific resistance genes are part of plant immunity system and trigger immunity reaction in the presence of the corresponding Avr effectors. Based on the combination of Avr genes in $P$. sojae and $R$ genes in soybean, the races of pathogen are defined. There are over 70 different races of this pathogen. Distribution of specific race is different and can be very variable. Studies have shown that races of $P$. sojae vary geographically. For example, dominant races in Heilongjiang province in China are 1, 3, 4, 5, 9, 13, 44, and 54, whereas race 1 and 3 are predominant (Zhang et al. 2010). In Iowa, USA, dominant races were 3,1 and 4 in 1991, and 1, 3 and 25 in 2001, while races 20,25, 28 and 35 have become increasingly important during the last ten years (Robertson \& Yang 2004). Due to the large number of races, sometimes it is very difficult to recommend a resistant variety for use. In Iowa case, the most common resistance gene in commercial varieties is $R p s 1 \mathrm{k}$ gene, but in some cases it is also necessary to include $R p s 6$ gene. These two genes have some overlapping in race specificity, and planting varieties with two resistance genes can provide longer protection. Another problem with soybean resistance to $P$. sojae is the fact that one field can be infested with several different races of pathogen. Robertson et al. 2007 found nine races in one commercial soybean field with $P$. sojae history. They concluded that the diversity of $P$. sojae population in each field was sufficient to defeat all 14 known Rps genes. It means that no soybean varieties are known to have complete resistance to $P$. sojae. This is only an illustration of diversity and complexity in dealing with soybean resistance to $P$. sojae.

There are several Avr effectors in $P$. sojae and some of them are genetically linked: Avr $1 \mathrm{~b}$, Avr1a, Avr3a/5, Avr3c, Avr4/6, Avr1k, Avrla, and $A v r 3 c$ (Dong et al. 2011a). Most typical for these oomycete Avr genes encode the predicted secreted proteins with a conserved motif consisting of RXLR (Arg-any amino acid-Leu-Arg). The RXLR effectors are large and rapidly evolving gene families, and in P. sojae genome there are 396 RXLR effectors genes (Jiang et al. 2008, Tyler et al. 2006). Another advantage to $P$. sojae in overcoming resistance in host plant is illustrated by $A v r 3 a / 5$ gene. This locus is highly polymorphic, displays copy number variation, sequence polymorphisms, and transcriptional differences among $P$. sojae strains (Dong et al. 2011b).

In soybean genome there are several $P$. sojae resistance genes ( $R$ genes) located on different chromosomes. The $R$ genes in soybean genome are usually organized in clusters, and the genes within one cluster mostly derive from the same ancestor (Richly et al. 2002). One of the most common $R$ genes in commercial cultivars is $R p s 1 \mathrm{k}$, mapped at $28 \mathrm{cM}$ on LG N, because $R p s 1 \mathrm{k}$ provides resistance to most races of pathogen. The $R p s 1 \mathrm{k}$ is coiled coil-nucleotide binding-leucine rich repeat (CC-NB-LRR)-type resistance genes, and trigger plant immunity in the presence of specific Avr effectors (Gao \& Bhattacharyya 2008). Due to pathogen races changes over time and specific spatial distribution, introgression of new resistance genes into commercial varieties is the major task for soybean breeders.

\section{Sclerotinia sclerotiorum}

S. sclerotiorum causes white mold and is potentially the most harmful fungal disease in soybean. The damage is greatest when infections occur during flowering, pod formation and grain filling (growth stages from R2 to R5). Since infected plants completely rot, yield reduction is almost identical with percentage of infected plants (Vidić 1982a). Sinclair \& Backman (1989) reported that the intensity of infection of $10 \%$ reduces yield by $0.25 \mathrm{t} / \mathrm{ha}$. However, a significant reduction in yield occurs in years with heavy, continuous rainfall during summer (Vidić 1992).

S. sclerotiorum is a polyphagous pathogen that parasitizes more than 400 , mostly broadleaf plant species. In addition to soybeans, host range of this fungus includes several crops, as well as a large number of weed species. Among many host plants, there are rare genotypes with complete resistance. However, it was reported that Phaseolus coccineus expresses resistant reaction to $S$. sclerotiorum (Adams et al. 1973), which are controlled by one dominant gene (Abawi et al. 1978). Soybean cultivars express significant variability in the degree of susceptibility to $S$. sclerotiorum in the field, but there are no data about resistant genotypes. However, several authors observed partial resistance. Thus Arahana et al. (2001) found this type of resistance, controlled by a few genes, in soybean cultivars Corsoy 79, DSR 137, S19-90 and Vinton 81. Yang et al. (1999) confirmed that cultivars Corsoy 79 and S19-90 are partially resistant, as well as line PI194639, reported by Calla et al. (2007). 
In our agro-ecological conditions, the latematuring genotypes (maturity group II and III) express a high degree of susceptibility, and when meteorological conditions are favourable for disease development, the appearance of white mould is more intense. In early-maturing genotypes (000 and 00) there are no symptoms of disease, or they are present in traces. However, early-maturing genotypes express a high level of susceptibility when infected under controlled conditions (Vidić et al. 1983). Therefore, genotypes with short vegetation do not have a complete physiological resistance; rather they avoid the attack of parasites in the field (Vidić 1992).

It is considered that physiological resistance and avoidance mechanisms cause differences in the response of soybean genotypes to $S$. sclerotiorum. Avoidance mechanisms of this parasite include early flowering and maturing, cultivars resistant to lodging, i.e. upright crop with good air circulation and fast drying inside the crop canopy. It has been shown that one or more of these factors can significantly reduce the intensity of white mold in soybean (Vidić 1982b, Boland \& Hall 1987, Nelson et al. 1991, Kim et al. 1999). Genetic evidence for physiological resistance and avoidance mechanisms were defined by Kim \& Diers (2000) in the process of mapping the three quantitative trait loci (QTL). Two loci control disease avoidance mechanisms and they are primarily associated with flowering time, plant height and lodging. The third locus probably causes partial physiological resistance.

Pathogenesis of $S$. sclerotiorum has been associated with fungal toxic secretion of oxalic acid (OA) (Cessna et al. 2000). There are three classes of known enzymes that can catabolize $\mathrm{OA}$, namely oxalate oxidase $(\mathrm{OXO})$, oxalate decarboxylase (OXDC), and bacterial oxalyl-CoA decarboxylase. The genes controlling OXO and OXDC enzymes have been utilized to produce soybean transgenic resistant plants. So, the plants which transformed with OXO $g f-2.8$ (germin) gene from wheat and decarboxylase $(o x d c)$ gene from a macrofungi Flammulina sp. showed high resistance to $S$. sclerotiorum (Cober et al. 2003, Lu 2003, Cunha et al. 2010). Considering the present results, it is evident that only a wider application of molecular markers will contribute to significant progress in developing commercial soybean genotypes, containing sufficient level of resistance to $S$. sclerotiorum.

\section{Macrophomina phaseolina}

M. phaseolina causes charcoal rot and summer wilt in soybeans. This thermophilic fungus favours droughtandwarmclimate. In tropicaland subtropical zone it causes decay of seedlings, significantly reducing the crop canopy (Gangopadhyay et al. 1973). In Serbia the disease appears in the generative phase of plant growth, especially on plants weakened by drought. The infection first occurs on root, and then on the lower part of stem and upper root area. During dry and hot summer, $40-50 \%$ of plants may be infected, resulting in yield reduced by $20-25 \%$ (Aćimović 1988). It was found that the fungus negatively affected all major components of soybean yield (Vidić et al. 1995).

Breeding for resistance to $M$. phaseolina is closely associated with drought tolerance. Specific resistance to $M$. phaseolina does not exist, but it was found that cultivars DeltaPineland 3478, Hamilton, Jakson II, Davis \& Asgrow 3715 expressed moderately resistant or tolerant response (Smith \& Carville 1997, Smith \& Wyllie 1999). The mechanism of soybean tolerance to drought is often equated with resistance to charcoal rot. Therefore, cultivation of genotypes whose generative phase of development does not coincide with dry period is recommended in the affected areas (Mengistu et al.2007). These authors suggested CFUI (colony-forming unit index) method to estimate the intensity of disease. Based on this index, soybean genotypes are classified into three groups: moderately resistant, moderately susceptible and susceptible. Thus, soybean line DT99-16864, DT99-17483, DT99-17554 and DT97-4290 express a moderate resistant reaction to M. phaseolina. By testing several soybean genotypes from III, IV and V maturity group (over 3 years), Mengistu et al. (2011) concluded that there are no resistant commercial cultivars. Moderately resistant cultivars were found among late-maturity genotypes (maturity group V). Similarly, in our agro-ecological conditions, earlymaturing genotypes express significantly higher susceptibility compared to the late-maturing genotypes (Vidić et al. 1994). Although there are soybean genotypes with a satisfactory level of resistance, not much has been done on the incorporation of resistance into commercial cultivars.

\section{Diaporthe phaseolorum var. caulivora, Diaporthe phaseolorum var. meridionalis}

Two varieties of $D$. phaseolorum cause stem canker in soybeans. This disease is the most widespread in soybean growing regions in the world. In Serbia, stem canker was observed and described in early 1980s (Jasnić \& Vidić 1981, 1983). Yield losses can be significant, especially when the symptom of 
canker appears earlier, and then plants wilt and dry in the middle of vegetation period.

Variability in the pathogenicity of $D$. phaseolorum var. caulivora was studied in detail both in the world and in our country. By testing a number of isolates of different geographic origin, Keeling (1984) allocated six physiological races based on reaction of six soybean cultivars. Isolates originating from the south of the United States were marked as southern races (1,2 and 3$)$, and isolates from north as northern races $(4,5$ and 6$)$. Later, similar studies indicated the existence of only two races - northern and southern races (Higley \& Tachibana 1987, McGee \& Beadle 1987). Since certain morphological differences were found between isolates from north and south, MorganJones (1989) considered these not as physiological races but two formae speciales. Based on molecular and morphological studies, Fernandez \& Hanlin (1996) suggested that these fungi should be classified into two varieties of $D$. phaseolorum as follows: D. phaseolorum var. caulivora (the agent of "northern" stem canker) and D. phaseolorum var. meridionalis (the agent of "southern" stem canker), which was accepted. Based on the reactions of test genotypes, it was determined that isolates originating from different regions of Serbia were identical to the $D$. phaseolorum var. caulivora, meaning that the "northern" type of stem canker in soybean is present in this country (Vidić 1991, Vidić et al. 1994).

For resistance to stem canker, Kilen \& Hartwig (1987) identified $R d c 1$ and $R d c 2$ genes in cultivars Tracy M, and later found $R d c 3$ and $R d c 4$ genes in cultivars Crockett, Dowling and Hutcheson (Bowers et al. 1993, Tyler 1996, Pioli et al. 2003). It has been proven that resistance to $D$. phaseolorum var. meridionalis is controlled by these four major genes, but they do not confer resistance to D. phaseolorum var. caulivora (Pioli et al. 2003). Therefore, Pioli et al. (2003) have proposed renaming of $R d c 1, R d c 2, R d c 3$ and $R d c 4$ genes to $R d m 1, R d m 2, R d m 3$, and $R d m 4$, respectively. $D$. phaseolorm var. meridionalis was not recorded on soybean in Europe for now, but given the climate change, its appearance is not excluded. Specific resistance to $D$. phaseolorum var. caulivora has not yet been found, but examination of different soybean genotypes has shown the presence of large differences in susceptibility (Vidić 1991). It was found that the reaction of soybean genotypes depends on the maturity group. Early-maturing genotypes were less susceptible to parasite attack and usually responded with mild symptoms (stem blight), while the late-maturing genotypes were much more susceptible and symptoms were manifested in the form of premature wilting in plants. Based on this, it can be concluded that early-maturing genotypes avoid the attack of parasites. However, in addition to early-maturing genotypes, a satisfactory level of resistance in the field is also expressed in SRF-100, Reiner and Harosoy 63, genotypes with longer vegetation (Vidić et al. 1990). Moderately susceptible reaction to $D$. phaseolorum var. caulivora was expressed in commercial cultivars Afrodita and Sava (personal observations).

\section{Phomopsis longicolla}

P. longicolla is the primary agent of soybean seed decay (Sinclair 1993), but this disease can also be caused by other members of the genus Diaporthe/Phomopsis. The disease is widespread in the world (McGee, 1992), and is also present in soybean in Serbia (Vidić et al. 2011). It can cause significant economic losses due to yield reduction and technological quality of grain. It has a negative effect on germinability, vitality and quality (Hepperly \& Sinclair 1978, Rupe 1990, Wrather et al. 2004, Wrather \& Koenning 2009, Koenning 2010). The agents of soybean seed decay favour long rainy and warm periods during soybean maturation and harvest (Balducchi \& Mcgee 1987, Hartman et al., 1999, Vidić et al. 2006). Considerable attention was given to finding sources of resistance to P. longicolla and studying the mode of inheritance, especially in the United States. The list of genotypes with different levels of resistance was given by Smith et al. (2008). According to these authors, a satisfactory level of resistance is expressed by several introduced genotypes (PI) and cultivars: PI181550, PI227687, PI229358, PI200510, PI209908, Arksoy, PI80837, PI417479, PI360841 and OX615. In addition, $\mathrm{Li}$ (2011) selected 26 introduced soybean lines with some degree of resistance, thereby indicating that the studied genotypes do not express the same reaction in different regions of the United States. Interesting results were obtained when testing the reaction of NS-cultivars and lines to P. longicolla. It has been shown that the response of seeds before maturity, when plants were infected by spraying with conidial suspension (phenophase R6-R7), did not correlate to the reaction of mature seeds, when tested on filter paper. Thus, line NS-L-220159 expresses a high level of resistance in mature seeds, and is very susceptible when plants are infected with conidial suspension. In spontaneous infections in the field, early-maturing genotypes expressed higher susceptibility than the late-maturing (Vidić et al. 1999). 
Table 1. Review of soybean resistance to pathogens. (see text for detailed information)

\begin{tabular}{|c|c|c|}
\hline Pathogen & $\begin{array}{c}\text { Number of known } \\
\text { races }\end{array}$ & Resistance in soybean \\
\hline Peronospora manshurica & over 40 & Rpmx, Rpm, Rpm1 \\
\hline Pseudomonas syringae pv. glycinea & 12 & Rpg1, Rpg2, Rpg3, Rpg5, Rpg6, Rpg7 \\
\hline Phytophthora sojae & over 70 & $\begin{array}{c}\text { Rps1, Rps2, Rps3, Rps4, Rps5, Rps6, Rps7, } \\
\text { Rps8; (multiple alleles) }\end{array}$ \\
\hline Sclerotinia sclerotiorum & not known & $\begin{array}{c}\text { Partial resistance, QTL, disease escape, } \\
\text { transgenic }\end{array}$ \\
\hline Macrophomina phaseolina & not known & Partial resistance, QTL \\
\hline Diaporthe phaseolorum var. caulivora & not known & not known \\
\hline Diaporthe phaseolorum var. meridionalis & not known & Rdm1, Rdm2, Rdm3, Rdm4 \\
\hline Phomopsis longicolla & not known & several genes \\
\hline
\end{tabular}

The mode of inheritance of resistance to $P$. longicolla is still not fully understood, and the results of some studies suggest that it is a quantitative trait conditioned by one or more genes. So, Zimmerman \& Minor (1993) found that resistance in the introduced line PI417479 is controlled by the expression of two dominant complementary genes, which can be successfully transferred using backcrosses. This genotype was used in order to develop MO/PSD-0259 lines with a single resistance gene (Jackson et al. 2005, 2009). It appears that another gene from PI 417479 was lost during the selection process. Resistance in PI80837 is also conditioned by a single dominant gene, which is not identical to the resistance gene in MO/PSD-0259 (Jackson et al. 2005). Recently, Smith et al. (2008) found that the resistance in PI360841 was controlled by two complementary genes, one of which is identical to the gene in PI80387, and both differ from the resistance genes in MO/PSD-0259. From the review, it is evident that there are several sources of resistance within different genotypes, allowing the successful breeding for resistance to this parasite in soybeans.

\section{Conclusions}

Based on the results overview in long term national and international research of soybean resistance to parasites as disease agents (Table 1.), the following conclusions can be drawn:

Soybean breeding for resistance to parasites, regarding the development and propagation of disease resistant and less susceptible varieties, represents one of the most efficient methods for disease control in this plant species.

Physiological (specific) resistance to Peronospora manshurica, Phytophthora sojae, Diaporthe phaseolorumvar.meridionalis, Pseudomonassyringae pv. glycinea (except in race 4 of this pathogen), and some other less significant soybean pathogens in Serbia, is observed in soybean genotypes. Avirulence genes in pathogens and resistance genes in soybean genotypes were identified and marked. Race composition in mentioned parasites and mode of inheritance of resistance were studied.

Partial resistance to Sclerotinia sclerotiorum, Diaporthe phaseolorum var. caulivora, Macrophomina phaseolina, and causative agents of soybean Phomopsis seed decay is detected. This type of resistance is caused by the cumulative action of disease escape mechanisms (early flowering and maturity, resistance to lodging, specific plant architecture, etc.) and physiological resistance. 


\section{References}

Abawi, G.S., Provvidenti, R., Croizer, D.C., \& Hunter, J.E. (1978). Inheritance of resistance to white mold disease in Phaseolus cocineus.J Hered, 69, 200-202.

Abo-Moch, F., Mavridis, A., \& Rudolph, K. (1995). Determination of Races of Pseudomonas syringae pv. glycinea Occurring in Europe. Journal of Phytopathology, 143(1), 1-5. doi:10.1111/ j.1439-0434.1995.tb00190.x

Aćimović, M. (1988). Prouzrokovači bolesti soje i njihovo suzbijanje. Beograd: Naučna knjiga.

Adams, P.B., Tate, C.J., Lumsden, R.D., \& Meiners, J.P. (1973). Resistance of Phaseolus species to Sclerotinia sclerotiorum. Rept Bean Improv Crop, 16, 8-9.

Arahan, W.V., Graef, L.G., Specth, E.J., Steadman, R.J., \& Eskridge, M.K. (2001). Identification of QTLSs for Resistance to Sclerotinia sclerotiorum in Soybean. Crop Science, 41, 180-188.

Athow, K.L. (1973). Fungal diseases. In B.E. Caldwell (Ed.), Soybeans: Improvement, production and uses. Agr. Monogr. (pp. 459-489). Madison WI: ASA.

Balaž, J., \& Aćimović, S. (2008). Bakterioze soje. Biljni lekar, 34(3), 226-235. Retrieved from http://scindeks.ceon.rs/article.aspx ?artid $=0354-61600804226 \mathrm{~B}$

Balaž, J., Arsenijević, M., \& Vidić, M. (1990). Bakteriološke karakteristike i fiziološke rase Pseudomonas syringae pv. glycinea (Caorper) Young, Dye et Wilkie parazita soje. Zaštita bilja, 193, 423-429.

Balducchi, A.J., \& McGee, D.C. (1987). Environmental Factors Influencing Infection of Soybean Seeds by Phomopsis and Diaporthe Species During Seed Maturation. Plant Disease, 71(3), 209-222. doi:10.1094/PD-71-0209

Bernard, R.L., \& Cremeens, C.R. (1971). A gene for general resistance to downy mildew of soybean.J Hered, 16, 359-362.

Boland, G.J., \& Hall, R. (1987). Evaluating Soybean Cultivars for Resistance to Sclerotinia sclerotiorum Under Field Conditions. Plant Dis, 71(10), 934-936. doi:10.1094/PD-71-0934

Bowers, G.R., Ngeleka, K., \& Smith, O.D. (1993). Inheritance of sten canker resistance in soybean cultivars Crockett and Dowling. Crop Science, 33, 67-70

Calla, B., Zhang, Y., Simmonds, D., \& Clough, S.J. (2007). Genomic analisis of soybean resistance to Sclerotinia sclerotiourm. In: Plant and Animal Genome XV Conference. 284.

Cessna, S.G., Sears, V.E., Dickman, M.B., \& Low, P.S. (2000) Oxalic acid, a pathogenicity factor for Sclerotinia sclerotiorum, suppresses the oxidative burst of the host plant. Plant Cell, 12(11), 2191-200. pmid:11090218

Chowdhury, A.K., Srinives, P., Saksoong, P., \& Tongpamnak, P. (2002). RAPD markers linked to resistance to downy mildew disease in soybean. Euphytica, 128(1), 55-60.

Cross, J.E., Kennedy, B.W., Lambert, J.W., \& Cooper, R.L. (1966). Patogenic races of the bacterial blight pathogen of soybeans. Pseudomonas glycinea. Plant Dis Rep, 50, 557-560.

Cunha, W.G., Tinoco, M.L.P., Pancoti, H.L., Ribeiro, R.E., \& Aragao, F.J.L. (2010). High resistance to Sclerotinia sclerotiorum in transgenic soybean plants transformed to express an oxalate decarboxylase gene. Plant Pathology, 59(4), 654-660.

Dong, S., Yin, W., Kong, G., Yang, X., \& Qutob, D. (2011). Phytophthora sojae Avirulence Effector Avr3b is a Secreted NADH and ADP-ribose Pyrophosphorylase that Modulates Plant Immunity. PLoS Pathog, 7(11), 1002353. doi:10.1371/ journal.ppat.1002353

Dong, S., Yu, D., Cui, L., Qutob, D., \& Tedman-Jones, J. (2011). Sequence Variants of the Phytophthora sojae RXLR Effector Avr3a/5 Are Differentially Recognized by Rps3a and Rps5 in Soybean. PLoS ONE, 6(7), 20172. doi:10.1371/journal. pone.0020172

Dunleavy, J.M. (1971). Races of Peronospora manshurica in the United States. Am J Bot, 58, 209-211.
Dunleavy, J.M. (1977). Nine new races of Peronospora manshurica found on soybeans in the Midwest. Plant Dis Rep, 61, 661-663.

Dunleavy, J.M. (1987). Yield Reduction in Soybeans Caused by Downy Mildew. Plant Dis, 71(12), 1112-1114. doi:10.1094/ PD-71-1112

Ersek, T., Holliday, M., \& Keen, N.T. (1982). Association of hypersensitive host cell death and autofluorescence with a gene for resistance to Peronospora manshurica in soybean. Phytopathology, 72, 629-631.

Farhatullah, Stayton, M.M., Groose, R.W., \& Khan, M.J. (2011). Genetic analysis of race-specificity of Pseudomonas syringae pv. glycinea. PakJ Bot, 43(1), 7-13.

Fernandez, F.A., \& Hanlin, R.T. (1996). Morphological and RAPD analyses of Diaporthe phaseolorum from soybean. Mycologia, 88(3), 425-440. doi:10.2307/3760884

Fett, W., \& Sequera, L. (1981). Futher characterization of physiological races of Pseudomonas glycinea. Can J Bot, 59, 283287.

Gangopadhyay, S.D., Agarwal, K., Sarbhoy, A.K., \& Wadhi, S.R. (1973). Charcoal rot disease of soybean in India. Indian Phytopath, 26, 730-732. (Abstr.).

Gao, J. (1998). Phisiologocal specialization of the bacterial blight pathogen of soybeans Pseudomonas syringae pv. glycinea. Journal of Jiling Agricultural University, 20, 10-12.

Gao, H., \& Bhattacharyya, M.K. (2008). The soybean-Phytophthora resistance locus Rps1-k encompasses coiled coil-nucleotide binding-leucine rich repeat-like genes and repetitive sequences. BMC Plant Biology, 8(1), 29. doi:10.1186/14712229-8-29

Geesman, G.E. (1950). Physiologic races of Peronospora manshurica on soybeans. Agron J, 42, 257-258.

Geesman, G.E. (1950). Inheritance of resistance of soybeans to Peronospora manshurica. Agron J, 42, 608-613.

Grabe, D.F., \& Dunleavy, J.M. (1959). Physiologicspecialization in Peronospora manshurica. Phytopathology, 49, 791-793.

Hartman, G.L., Sinclair, J.B., \& Rupe, J.C. (1999). Compendium of Soybean Diseases, 4th. St. Paul, Minnesota, USA: American Phytopathological Society.

Hepperly, P.R., \& Sinclair, J.B. (1978). Quality Losses in Phomopsis-Infected Soybean Seeds. Phytopathology, 68(12), 1684-1687. doi:10.1094/Phyto-68-1684

Higley, P.M., \& Tachibana, H. (1987). Physiologic Specialization of Diaporthe phaseolorum var. caulivora in Soybean. Plant Disease, 71(9), 815-817. doi:10.1094/PD-71-0815

Ignjatov, M. (2007). Bakteriozna pegavost soje u Vojvodini. Novi Sad: Poljoprivredni fakultet.

Jackson, E.W., Feng, C., Fenn, P., \& Chen, P. (2009). Genetic mapping of resistance to Phomopsis seed decay in the soybean breeding line MO/PSD-0259 (PI562694) and Plant Introduction 80837. J Hered, 100(6), 777-83. pmid:19589849

Jackson, E.W., Fenn, P., \& Chen, P. (2005). Inheritance of resistance to Phomopsis seed decay in soybean PI80837 and MO/ PSD-0259 (PI562694). Crop Science, 45, 2400-2404.

Jasnić, S., \& Vidić, M. (1981). Crna pegavost stable nova bolest soje u Jugoslaviji. Glasnik zaštite bilja, 2, 44-46.

Jasnić, S., \& Vidić, M. (1983). Diaporthe phaseolorum var. caulivora - nov parazit soje u Jugoslaviji. Zaštita bilja, 164, 213 223.

Jiang, R.H.Y., Tripathy, S., Govers, F., \& Tyler, B.M. (2008). RXLR effector reservoir in two Phytophthora species is dominated by a single rapidly evolving superfamily with more than 700 members. Proceedings of the National Academy of Sciences, 105(12), 4874-9. pmid:18344324

Keeling, B.L. (1984). Evidence for physiologic specialization in Diaporthe phaseolorum var. caulivora. Journal of Mississippi Academi of Science, 29(suppl), 5.

Keen, N.T., \& Buzzell, R.I. (1991). New disease resistance genes in soybean against Pseudomonas syringae pv glycinea: eviden- 
ce that one of them interacts with a bacterial elicitor. Theoretical and Applied Genetics, 81(1), 133-8.

Keith, L.W., Boyd, C., Keen, N.T., \& Partridge, J.E. (1997). Comparison of avrD alleles from Pseudomonas syringae pv. glycinea. Molecular Plant-Microbe Interactions, 10(3), 416-422.

Kennedy, B.W., \& Alcorn, S.M. (1980). Estimates of U.S. crop losses to procaryote plant pathogens. Plant Disease, 64, 674676.

Kilen, T.C., \& Hartwig, E.E. (1987). Identification of single genes controlling resistance to stem canker in soybean. Crop Science, 27, 220-222.

Kim, H.S., \& Diers, B.W. (2000). Inheritance of parial resistance to sclerotinia stem rot in soybean. Crop Science, 40, 55-61.

Kim, H.S., Sneller, C.H., \& Diers, B.W. (1999). Evaluation of soybean cultivars to sclerotinia stem rot in field environments. Crop Science, 39, 64-68.

Kobayashi, D.Y., Tamaki, S.J., \& Keen, N.T. (1989). Cloned avirulence genes from the tomato pathogen Pseudomonas syringae pv. tomato confer cultivar specificity on soybean. Proceedings of the National Academy of Sciences, 86(1), 157-61. doi:10.1073/ pnas.86.1.157

Kobayashi, D.Y., Tamaki, S.J., \& Keen, N.T. (1990). Molecular characterization of avirulence gene D from Pseudomonas syringae pv. tomato. Molecular plant-microbe interactions, 3(2), 94-102. pmid:2132028

Koenning, S.R. (2010). Southern United States soybean disease loss estimate for 2009. In: Proceedings of the Southern Soybean Disease Workers, the 37th Annual Meeting. 1.

Lehman, S.G. (1953). Race 4 of the soybean downy mildew fungus. Phytopathology, 43, 460-461.

Li, S. (2011). Phomopsis Seed Decay of Soybean. In A. Sudarić (Ed.), Molecular Aspects of Breeding. (pp. 277-292). InTech.

Lim, S.M. (1989). Inheritance of resistance to Peronospora manshurica races 2 and 33 in soybean. Phytopathology, 79(8), 877 879. doi:10.1094/Phyto-79-877

Lim, S.M., Bernard, R.L., Nickell, C.D., \& Gray, L.E. (1984). New physiological race of Peronospora manshurica virulent to the gen Rpm in soybeans. Plant Dis, 68, 71-72.

Lu, G. (2003). Engineering Sclerotinia sclerotiorum resistance in oilseed crops. African Journal of Biotechnology, 2(12), 509516.

Marcinkowska, J. (1991). Physiological specialization of Peronospora manshurica in Poland. Eurosya, 7-8, 55-58.

Mcgee, D.C. (1992). Soybean Diseases. A reference source for seed technologists. St. Paul, Minesota: The American Phytopathological Society.

Mcgee, D.C., \& Bidle, J.A. (1989). Seedborne Diaporthe phaseolorum var. caulivora in Iowa and its Relationship to soybean stem canker in the southern United States. Plant Disease, 71, 620-622.

Mengistu, A., Arelli, P.A., Bond, J.P., Shannon, G.J., Wrather, A.J., Rupe, J.B., . . Pantalone, V.R. (2011). Evaluation of soybean genotypes for resistance to charcoal rot. Plant Health Progress, Online. doi:10.1094/PHP-2010-0926-01-RS

Mengistu, A., Ray, J.D., Smith, J.R., \& Paris, R.L. (2007). Charcoal rot disease assessment of soybean genotypes using a colonyforming unit index. Crop Science, 47(86), 2453-2461.

Morgan-Jones, M. (1989). The Diaporthe/Phomopsis complex: Taxonomic considerations. In: World Soybean Reshers Conference, Buenos Aires, Argentina. 1699-1706.

Nelson, B.D., Helms, T.C., \& Olson, M.A. (1991). Comparison of laboratory and field evaluations of resistance in soybean to Sclerotinia sclerotiorum. Plant Dis, 75, 662-665.

Pioli, R.N., Morandi, E.N., Martínez, M.C., Lucca, F., Tozzini, A., Bisaro, V., \& Hopp, E.H. (2003). Morphologic, Molecular, and Pathogenic Characterization of Diaporthe phaseolorum Variability in the Core Soybean-Producing Area of Argentina. Phytopathology, 93(2), 136-46. pmid: 18943127
Richly, E., Kurth, J., \& Leister, D. (2002). Mode of amplification and reorganization of resistance genes during recent Arabidopsis thaliana evolution. Mol Biol Evol, 19(1), 76-84. pmid:11752192

Robertson, A., Cianzio, S., \& Cerra, S. (2007). Populations of Phytophthora sojae are diverse within single fields. Integrated cropmanagement, 498(15),

Robertson, A., \& Yang, X.B. (2004). Update of Phytophthora races present in Iowa. Integrated crop management, 492(12),

Roy, K.W., Baird, R.E., \& Abney, T.S. (2000). A review of soybean (Glycine max) seed, pod, and flower mycofloras in North America, with methods and a key for identification of selected fungi. Mycopathologia, 150(1), 15-27.

Rupe, J.C. (1990). Effects of temperature on the rate of infection of soybean seedling by Phomopsis longicolla. Can J Plant Pathol, 12, 43-47.

Sinclair, J.B. (1993). Phomopsis seed decay of soybeans - a prototype for studying seed disease. Plant Dis, 77, 329-334.

Sinclair, J.B., \& Shurtleff, M.C. (1975). Compendium of Soybean Disease. Minnesota, USA: The American Phytopathological Society, Inc.

Sinclair, J.B., \& Backman, P.A. (1989). A compendium of soybean diseases, 3rd. St. Paul, Minnesota, USA: American Phytopathological Society.

Smith, G.S., \& Carvil, O.N. (1997). Field screening of commercial and experimental soybean cultivars for their reaction to Macrophomina phaseolina. Plant Disease, 81(4), 363-368.

Smith, G.S., \& Wyllie, T.D. (1999). Charcoal rot. In G.L. Hartman, J.B. Sinclair, \& J.C. Rupe (Eds.), Compendium of Soybean Disease, 4th. (pp. 29-31). St. Paul, MN, USA: American Phytopathological Society.

Smith, S., Fenn, P., Chen, P., \& Jackson, E. (2008). Inheritance of Resistance to Phomopsis Seed Decay in PI 360841 Soybean. Journal of Heredity, 99(6), 588-592.

Staskawics, B., Dahlbeck, D., Keen, N., \& Napoli, C. (1987). Molecular characterization of cloned avirulence genes from race $\mathrm{O}$ and race 1 of Pseudomonas syringae pv. glycinea. Journal of Bacteriology, 169, 5789-5794.

Staskawics, B.J., Dahlbeck, J.D., \& Keen, N.T. (1984). Cloned Avirulence Gene of Pseudomonas syringae pv. glycinea Determines Race-Specific Incompatibility on Glycine max (L.) Merr. Proceedings of the National Academy of Sciences, 81(19), 6024-6028. doi:10.1073/pnas.81.19.6024

Tošić, M., Panić, M., Stojanović, T., \& Antonijević, D. (1986). Bolesti soje na području SR Srbije u 1985. godini. In Zbornik radova Republičkog savetovanja o unapredenju proizvodnje soje, suncokreta i uljane repice. (pp. 1-21).

Tyler, B.M., Tripathy, S., Zhang, X., Dehal, P., Jiang, R.H.Y., Aerts, A., ... Damasceno, C.M.B. (2006). Phytophthora genome sequences uncover evolutionary origins and mechanisms of pathogenesis. Science, 313(5791), 1261-6. pmid:16946064

Tyler, J.M. (1996). Characterization of stem canker resistance in Hutcheson soybean. Crop Science, 36, 591-593.

Vidić, M. (1982). Sclerotinia sclerotiorum (Lib.) De Bary parazit soje u SAP Vojvodini. Novi Sad: Poljoprivredni fakultet.

Vidić, M. (1982). Uticaj nekih agrotehničkih mera na intenzitet pojave bele truleži na soji. Savremena poljoprivreda, 30(11-12), 587-597.

Vidić, M. (1991). Variability of Diaporthe phaseolorum var. caulivora on soybean in the Vojvodina province in Serbia. Zaštita bilja, 197, 183-189.

Vidić, M. (1992). Epidemiološke karakteristike najznačajnijih parazita soje u Vojvodini. Zbornik radova Instituta za ratarstvo $i$ povrtarstvo, Novi Sad, 20, 519-522.

Vidić, M., \& Balaž, J. (1997). Reakcija genotipova soje prema Pseudomonas syringae pv. glycinea. Zaštita bilja, 48(2), 119-125.

Vidić, M., Hrustić, M., Rajičić, M., \& Relić, S. (1995). Uticaj Macrophomina phaseolina na prinos i komponente prinosa soje. Zaštita bilja, 46(4), 285-291. 
Vidić, M., \& Jasnić, S. (2008). Bolesti soje. In J. Miladinović, M. Hrustić, \& M. Vidić (Eds.), Soja. (pp. 370-447). Novi Sad i Bečej: Institut za ratarstvo i povrtarstvo i Sojaprotein.

Vidić, M., Jasnić, S., \& Ammar, M. (1983). Osetljivost nekih sorti soje prema beloj truleži (Sclerotinia sclerotiorum). Zaštita bilja, 34(4), 503-512.

Vidić, M., Jasnić, S., \& Đorđević, V. (2006). Rasprostranjenost Diporthe/Phomopsis vrsta na semenu soje u Srbiji. Pesticidi $i$ fitomedicina, 21(1), 39-48.

Vidić, M., Jasnić, S., Hrustić, M., \& Jocković, Đ. (1994). Uticaj roka setve soje na intenzitet napada Macrophomina phaseolina (Tassi) Goid. Zbornik radova Instituta za ratarstvo i povrtarstvo, Novi Sad, 22, 211-219.

Vidić, M., Jasnić, S., Hrustić, M., \& Miladinović, J. (1999). Reakcija genotipova soje prema Phomopsis longicolla prouzrokovaču truleži semena. Zaštita bilja, 50(3), 229-238.

Vidić, M., Jasnić, S., Jocković, Đ., \& Hrustić, M. (1990). Reakcija sorti i linija soje prema Diaporthe phaseolorum var. caulivora. Zaštita bilja, 191, 31-39.
Vidić, M., Jasnić, S., \& Petrović, K. (2011). Vrste roda Diaporthe/Phomopsis na soji u Srbiji. Pestic Fitomed (Beograd), 26(4), 301-315. doi:10.2298/PIF1104301V

Williams, D.J., \& Nyvall, R.F. (1980). Leaf infection and yield losses caused by brown spot and bacterial blight diseases of soybean. Phytopathology, 70, 900-902.

Wrather, J.A., \& Koenning, S.R. (2009). Effects of diseases on soybean yields in the United States 1996 to 2007. Plant Health Progress, Online. doi:10.1094/PHP-2009-04401-01-RS

Wrather, J.A., Shannon, J.G., Stevens, W.E., Sleper, D.A., \& Arelli, A.P. (2004). Soybean cultivar and foliar fungicide effects on Phomopsis sp. seed infection. Plant Dis, 88(7), 721-723.

Yang, X.B., Lundeen, P., \& Uphoff, M.D. (1999). Soybean Varietal Response and Yield Loss Caused by Sclerotinia sclerotiorum. Plant Dis, 83, 456-461.

Zhang, S.Z., Xu, P.F., Wu, J.J., Xue, A.G., Zhang, J.X., Li, W.B., . . Lv, H.Y. (2010). Races of Phytophthora sojae and their virulences on soybean cultivars in Heilongjiang, China. Plant Dis, 94, 87-91.

Zimmerman, M.S., \& Minor, H.C. (1993). Inheritance of Phomopsis seed decay resistance in soybean PI 417479. Crop Science, 32, 96-100.

\section{Otpornost soje prema patogenima}

\section{Miloš Vidić • Vuk Đorđević • Kristina Petrović • Jegor Miladinović}

Sažetak: Na osnovu višegodišnjih istraživanja utvrđeno je da su najštetniji i najrasprostranjeniji paraziti soje u Srbiji $P e$ ronospora manshurica (prouzrokovač plamenjače), Pseudomonas syringae pv. glycinea (bakteriozna pegavost), Sclerotinia sclerotiorum (bela trulež), Diaporthe phaseolorum var. caulivora (rak stabla), Macrophomina phaseolina (ugljenasta trulež) i Phomopsis spp. (trulež semena). Postoji realna opasnost da se na soji u našoj zemlji pojave i dva veoma destruktivna parazita; Phytophthora sojae, prouzrokovač fitoftorozne truleži i Diaporthe phaseolorum var. meridionalis prouzrokovač “južnog” raka stabla.

Unošenje otpornosti prema najznačajnijim parazitima u nove sorte soje je jedan od prioritetnih zadataka svih oplemenjivačkih programa. Najpre je potrebno iznaći odgovarajući izvor otpornosti, zatim obaviti povratna ukrštanja i u kasnijim generacijama identifikovati otporne genotipove. Uspeh u radu na stvaranju otpornih sorti soje uslovljen je postojanjem dobrih izvora rezistentnosti, kao i poznavanjem prirode otpornosti i načina nasleđivanja.

Rezistentnost prema $P$. manshurica evidentirana je u više genotipova soje, a najčešće je uslovljena jednim dominantnim genom (Rpm). Ova otpornost je potpuna, ali nije trajna, jer se postepeno gubi usled pojave novih fizioloških rasa. Rasa br. 4 P. syringae pv. glycinea je dominantna na soji u svetu i kod nas. Ne postoje potpuno otporni genotipovi prema ovoj rasi, ali su prisutne značajne razlike u stepenu osetljivosti. Parcijalna otpornost kontrolisana je od strane jednog ili nekoliko Rpg gena.

Mehanizmi izbegavanja oboljenja i parcijalna fiziološka rezistentnost uslovljavljaju razlike u reakciji sorti soje prema S. sclerotiorum. Mapirana su dva lokusa koji kontrolišu mehanizme izbegavanja bolesti i jedan lokus, najverovatnije odgovoran za parcijalnu fiziološku rezistentnost. Parcijalna rezistentnost utvrđena je kod nekoliko introdukovanih (PI) genotipova soje. U našim agroekološkim uslovima ranostasni genotipovi izbegavaju napad ovog oboljenja. Nije evidentirana potpuna otpornost prema $D$. phaseolorum var. caulivora, prouzrokovaču „severnog“ tipa raka stabla. Prouzrokovač ,južnog“ tipa raka stabla $D$. phaseolorum var. meridionalis nije prisutan na soji u Srbiji. Otpornost prema ovoj gljivi nađena je u nekoliko genotipova soje, a uslovljavaju je dva (delimična otpornost), odnosno, četiri (potpuna) major gena.

Pripadnici roda Diaporthe/Phomopsis su najštetniji paraziti semena soje, a vrsta P. longicolla je najzastupljenija. Zadovoljavajući nivo rezistentnosti prema ovom parazitu semena poseduje nekoliko genotipova soje. Priroda otpornosti nije u potpunosti razjašnjena, a novija istraživanja ukazuju da se radi o kvantitativnom svojstvu.

Brojna istraživanja posvećena su proučavanju Phytophthora sojae (fitoftorozna trulež), veoma štetnog parazita soje. Opisano je više od 70 fizioloških rasa, identifikovani su avirulentni geni (Avr) u pojedinim rasama i pronađeni su geni rezistentnosti (Rps) u sortama soje. Tako je omogućeno uspešno oplemenjivanje soje na otpornost prema ovom parazitu. 